\title{
HUBUNGAN SIKAP BELAJAR DAN MOTIVASI BELAJAR TERHADAP PRESTASI BELAJAR MATEMATIKA SISWA SMPN 6 LANGKE REMBONG
}

\author{
Frederik D.E Jemudin ${ }^{1}$, Alberta P. Makur ${ }^{2}$, Ferdinandus A. Ali ${ }^{3}$ \\ STKIP Santu Paulus, Jl. Ahmad Yani no 10, Ruteng, 86511, Indonesia ${ }^{1,2,3}$ \\ Email: alberta.makur@stkipsantupaulus.ac.id
}

\begin{abstract}
The purpose of this study was to determine the relationship between learning attitudes and student learning achievement; the relationship between learning motivation and student learning achievement; and the relationship between learning attitudes and motivational learning together towards student learning achievement. The correlational research method carried out this research. The population in this study were seventh-grade students of Langke Rembong 6 Junior High School, East Nusa Tenggara. Samples as subjects in this study were 46 students. Data collection was conducted using a questionnaire to obtain data on learning attitudes and learning motivation while the test instrument was used to gather data on mathematics learning achievement. The results showed that there was a positive and significant relationship between learning attitudes towards students' mathematics learning achievement. There is also a positive and significant relationship between learning motivation towards students' mathematics learning achievement. Furthermore, there is a positive and significant relationship between learning attitudes and learning motivation towards students' mathematics learning achievement together.
\end{abstract}

Keywords : Attitude of Learning, Learning Motivation, Mathematics Learning Achievement..

\section{PENDAHULUAN}

Pendidikan adalah kebutuhan mendasar yang harus dimiliki manusia, karena tanpa pendidikan manusia tidak bisa meningkatkan taraf hidupnya. Melalui pendidikan manusia akan lebih baik untuk mengembangkan dirinya. Seperti hal yang disebutkan dalam Undang-Undang Republik Indonesia Nomor 20 tahun 2003 tentang Sistem Pendidikan Nasional Bab 1 pasal 1, pendidikan adalah usaha sadar dan terencana untuk mewujudkan suasana belajar dan proses pembelajaran agar peserta didik secara aktif mengembangkan potensi dirinya untuk memiliki kekuatan spiritual keagamaan, 
pengendalian diri, kepribadian, kecerdasan, akhlak mulia, serta keterampilan yang diperlukan dirinya, masyarakat, bangsa dan negara

Sudarto (2016) menyatakan bahwa pendidikan sebagai suatu sistem yang terorganisir dengan baik serta memiliki potensi tersendiri. Adapun tujuan pendidikan memuat gambaran tentang nilai-nilai yang baik, luhur, pantas, benar, dan indah untuk kehidupan. Lebih lanjut dijelaskan, tujuan pendidikan memiliki dua fungsi yaitu memberikan arah kepada segenap kegiatan pendidikan dan merupakan sesuatu yang ingin dicapai oleh segenap kegiatan pendidikan.

Suherman (2003) menyatakan Matematika menempati posisi paling penting dalam kurikulum pendidikan nasional, matematika juga berperan sebagai ilmu pengetahuan yang tujuannya mencakup seluruh pengembangan potensi yang dimiliki siswa secara menyeluruh dan seimbang. Umumnya matematika dikenal dengan keabstrakannya disamping sedikit bentuk yang berangkat dari realita lingkungan manusia.

Pelajaran matematika ditegaskan dalam Kurikulum 2004 sebagaimana dijelaskan dalam Depdiknas (2003) bahwa pembelajaran matematika di sekolah bertujuan untuk mengembangkan potensi siswa yakni mengasah cara berpikir, bernalar dan melatih juga menarik kesimpulan dari hasil pikirannya. Disamping itu tujuan lainnya dari pembelajaran matematika disekolah juga untuk melatih siswa memecahkan masalah dan mengembangkan kemampuan berkomunikasi siswa melalui pembicaraan lisan maupun tulisan.

Proses sangat berguna dalam menanamkan sikap belajar kepada siswa. Skinner dalam teorinya (Ompusunggu, 2014) mengatakan bahwa pembentukan sikap belajar menekan pada reaksi atau respon anak. Pada saat anak menunjukkan sikap belajar yang baik harusnya diberikan penguatan berupa hadiah ataupun perilaku yang menyenangkan lama kelamaan anak akan meningkatkan sikap positifnya. Siagian (2015) mengatakan bahwa sikap belajar tidak dibentuk sejak lahir, melainkan dipelajari melalui pengalaman-pengalaman kesehariannya. Kartiwi (2011) mengungkapkan tentang struktur sikap belajar terdiri atas tiga komponen yang saling menunjang, yaitu: komponen kognitif, afektif dan konatif. Komponen kognitif yaitu representasi apa yang di percayai oleh individu pemilik sikap; komponen afektif, yaitu perasaan yang menyangkut emosional dan komponen konatif merupakan aspek kecendrungan berprilaku tertentu sesuai dengan sikap yang di miliki seseorang. 
Selain sikap belajar yang mempengaruhi prestasi belajar, Mukhtar (2015) menunjukkan bahwa prestasi belajar juga pada umumnya meningkat jika motivasi untuk belajar bertambah. Motivasi dibagi menjadi dua yaitu instrinsik dan ekstrinsik. Sesuai dengan pendapat Mukhtar yangmengatakan bahwa motivasi belajar siswa merupakan daya penggerak bagi siswa untuk melakukan sesuatu. Djali (2008) menyatakan motivasi merupakan kondisi fisiologis dan psikologis seseoranguntuk mendorong melakukan aktivitas tertentu guna mencapai tujuan atau kebutuhan yang di inginkan. Menurut Sardiman (2016) peran motivasi adalah menumbuhkan gairah dan semangat untuk belajar sehingga dapat dikatakan motivasilah yang mendorong siswa untuk melakukan kegiatan belajar.

Senada dengan masalah tersebut, hasil wawancara tidak terstruktur dengan salah seorang guru matematika di SMP Negeri 6 Langke Rembong pada saat peneliti melakukan Praktik Pengalaman Lapangan (PPL), sebagian besar siswa tidak menyukai matematika, hal ini ditandai dengan tingkah laku siswa ketika proses pembelajaran berlangsung, Guru matematika tersebut menyatakan bahwa sikap belajar dan juga motivasi belajar siswa masih sangat rendah. Ini dilihat dari banyak siswa yang masih ingin bermain, mengganggu teman yang sedang fokus mengikuti pelajaran, tidak serius mengikuti pelajaran, kadang pula sering didapati siswa yang sedang mengantuk ataupun sedang tidur. Kurangnya motivasi belajar siswa sehingga proses belajar siswa pun akan terhambat, walaupun masih ada juga siswa yang antusias mengikuti pelajaran matematika namun ketika ditanya siswa masih ragu untuk menjawab pertanyaan yang diajukan guru. Hal tersebut di atas menunjukan kurangnya motivasi yang dimiliki siswa dan sikap siswa yang tidak menyukai pelajaran matematika, ketidaksukaan siswa pada mata pelajaran matematika akan memiliki pengaruh yang besar terhadap sikap siswa dalam mempelajari matematika dan akan mempengaruhi juga terhadap prestasi belajar matematika siswa.

Berdasarkan uraian di atas, rumusan masalah dalam penelitian ini adalah: Apakah terdapat hubungan antara sikap belajar dan prestasi belajar siswa kelas VII SMPN 6 Langke Rembong Tahun Ajaran 2018/2019? Apakah terdapat hubungan antara motivasi belajar dan prestasi belajar siswa kelas VII SMPN 6 Langke Rembong Tahun Ajaran 2018/2019? Apakah terdapat hubungan antara sikap belajar dan motivasi belajar secara 
bersama-sama terhadap prestasi belajar siswa VII SMPN 6 Langke Rembong Tahun Ajaran 2018/2019?

\section{METODE PENELITIAN}

Tujuan penelitian ini adalah untuk mengetahui ada tidaknya hubungan antara sikap belajar dan prestasi belajar siswa; antara motivasi belajar dan prestasi belajar siswa; serta hubungan antara sikap belajar dan motivasi secara bersama-sama belajar terhadap prestasi belajar siswa kelas VII SMPN 6 Langke Rembong Tahun Ajaran $2018 / 2019$.

Desain dari penelitian ini adalah peneliti berusaha mengetahui dan mengkaji ada atau tidaknya hubungan sikap belajar dan motivasi belajar terhadap prestasi belajar matematika siswa, sehingga metode penelitian yang digunakan dalam penelitian ini adalah penelitian korelasional. Metode penelitian korelasional menurut Tanujaya, Mumu, dan Margono (2017), adalah tipe spesifik dari desain non-eksperimental yang digunakan untuk mempelajari hubungan antara dua variabel atau lebih. Penelitian ini merupakan penelitian untuk mengetahui hubungan dan keeratan hubungan antara dua variabel tanpa memanipulasi variabel. Penelitian korelasional mengacu pada studi di mana tujuannya adalah untuk menemukan hubungan antar variabel melalui penggunaan statistik korelasi.

Populasi dalam penelitian ini adalah siswa-siswi kelas VII SMP Negeri 6 Langke Rembong. Siswa kelas VII SMP Negeri 6 Langke Lembong pada tahun ajaran 2018/2019 yang terdiri dari 87 siswa yang terbagi dalam tiga rombongan belajar, yaitu dari kelas VIIA, VIIB, dan VIIC Dari populasi tersebut peneliti menggunakan teknik Random Sampling untuk menentukan jumlah Sampel penelitian. Setelah melakukan teknik Rendom Sampling peneliti memilih dua kelas untuk dijadikan sampel penelitian.

Instrumen yang digunakan dalam pengumpulan data dalam penelitian ini adalah angket dan tes. Angket yang digunakan dalam penelitian ini untuk mengukur Sikap Belajar dan Motivasi Belajar, sedangkan instrumen Tes digunakan untuk mengukur Prestasi Belajar dalam bentuk Pilihan Ganda.

Data yang diperoleh dianalisis dengan menggunakan metode korelasi. Korelasi adalah analisis statistika yang mengukur arak dan keeratan hubungan antara dua variabel (Tanujaya et al, 2017). Rumus yang digunakan untuk menghitung koefisien 
korelasi (r), sebagaimana dikemukakan oleh Moore, Notz, dan Fligner (2013) adalah sebagai berikut:

$$
r=\frac{1}{n-1} \sum\left(\frac{x_{i}-\bar{x}}{S_{x}}\right)\left(\frac{y_{i}-\bar{y}}{S_{y}}\right)
$$

Lebih lanjut Tanujaya et al (2017) menyatakan bahwa terdapat beberapa cara untuk menginterpretasi nilai koefisien korelasi. Penafsiran makna dari koefisien korelasi tergantung dari jenis penelitian dan tujuan penelitian. Namun demikian pada umumnya terdapat kriteria yang digunakan untuk menilai keeratan hubungan antara dua variable berdasarkan nilai koefisien korelasinya, sebagaimana disajikan pada Tabel 1.

Tabel 1. Kriteria hubungan antara dua variable berdasarkan nilai koefisien korelasi

\begin{tabular}{ccl}
\hline No. & Koefisien $(\mathbf{r})$ & \multicolumn{1}{c}{ Hubungan } \\
\hline 1. & $0,00-0,20$ & Sangat Rendah \\
2. & $0,20-0,40$ & Rendah \\
3. & $0,40-0,60$ & Sedang (Cukup Erat) \\
4. & $0,60-0,80$ & Erat \\
5. & $0,80-1,00$ & Sangat Erat \\
\hline
\end{tabular}

\section{HASIL DAN PEMBAHASAN}

Dari hasil perhitungan diperoleh nilai koefisien korelasi $r_{x 1 x 2 y}=0,613$. Besar sumbangan variabel sikap belajar matematika terhadap prestasi belajar matematika adalah sebesar $\mathrm{r}^{2} \times 100 \%=0,613^{2} \times 100 \%=37,576 \%$ dan sisanya dipengaruhi oleh variabel lain. Hasil uji signifikansi diperoleh nilai $t_{\text {hitung }}=7,068$. Berdasarkan perhitungan $\alpha=0,05$ dan $\mathrm{n}=46$ dan $d k=\mathrm{n}-2=46-2=44$ maka diperoleh nilai $t_{\text {tabel }}=$ 4,061. Ternyata $t_{\text {hitung }}>t_{\text {tabel }}$ yaitu 7,068 $>4,061$ dan koefisien korelasi bernilai positif, maka $\mathrm{H}_{0}$ ditolak. Hal ini mengandung pengertian bahwa terdapat hubungan positif yang signifikan antara sikap belajar dan motivasi belajar dengan prestasi belajar matematika siswa. Besar dan arah hubungan tersebut menunjukkan bahwa semakin tinggi sikap belajar dan motivasi belajar matematika siswa maka semakin tinggi pula prestasi belajar matematika siswa.

Menurut Walgito (2002), jumlah nilai yang di peroleh seseorang menggambarkan sikap orang terhadap sesuatu objek sikap. Makin tinggi skor yang diperoleh seseorang, merupakan indikasi bahwa orang tersebut sikapnya makin positif, sebaliknya semakin rendah skor yang diperoleh maka orang tersebut memiliki sikap yang semakin negatif. Dalam kaitannya dengan perolehan skor yang didapatkan dari hasil pengisian angket 
sikap belajar matematika dalam penelitian ini, skor yang paling rendah yang diperoleh siswa adalah 60 dan skor tertinggi yang diperoleh siswa adalah 71. Hasil tersebut mengandung pengertian bahwa siswa yang mendapatkan skor terendah ini memiliki sikap belajar matematika yang paling negatif, sedangkan siswa yang mendapat skor tertinggi ini adalah siswa yang memiliki sikap belajar matematika yang paling positif.

Lebih lanjut hasil penelitian tentang variabel Motivasi Belajar terhadap Prestasi Belajar diperoleh bahwa skor terendah yang diperoleh siswa adalah 50, sedangkan skor tertinggi adalah sebesar 70. Hal ini juga mengandung pengertian bahwa siswa yang mendapatkan skor terendah ini memiliki motivasi belajar matematika yang paling rendah (negatif), sedangkan siswa yang memperoleh skor tertinggi ini adalah siswa yang memiliki Motivasi belajar matematika yang paling tinggi (positif).

Salah satu tujuan dari penelitian ini adalah supaya mengetahui hubungan sikap belajar dan motivasi belajar, secara bersama terhadap prestasi belajar siswa. Selanjutnya dalam kaitannya dengan langkah-langkah penelitian, langkah awal yang dilakukan oleh peneliti dalam pelaksanaan penelitian ini, yaitu melakukan uji validitas dan uji reliabilitas terhadap instrumen angket sikap belajar dan motivasi belajar dan instrumen tes prestasi belajar matematika yang akan digunakan dalam penelitian. Soal-soal yang akan dilakukan Uji validitas dan uji reliabilitas diberikan kepada siswa diluar populasi penelitian yaitu kepada siswa kelas VII SMPN 6 Langke Rembong. Instrumen sikap belajar dan motivasi belajar dan prestasi belajar matematika yang telah lulus uji validitas dan reliabilitas, kemudian disebarkan pada sampel penelitian yang sebenarnya.

Langkah selanjutnya dalam penelitian ini, yaitu melakukan uji normalitas data, hal ini dilakukan untuk mengetahui penyebaran dari distribusi data yang ada dalam kondisi normal atau tidak. Berdasarkan hasil penelitian yang digunakan,diketahui bahwa hasil uji data sikap belajar, motivasi belajar dan hasil belajar dalam distribusi normal, maka dilanjutkan uji linearitas. Uji liniearitas bertujuan untuk mengetahui hubungan antara sikap belajar dan motivasi belajar terhadapprestasi belajar matematika. Berdasarkan hasil penelitian pengujian yang dihasilkan berpola linear.

Langkah selanjutnya adalah melakukan uji hipotesis dengan menggunakan rumus korelasi Pearson Product Moment. Berdasarkan hasil pengujian hipotesis, tampak bahwa nilai korelasi antara variabel sikap belajar dan variabel prestasi belajar matematika adalah sebesar 0,42 , sedangkan nilai korelasi antara motivasi belajar dan 
prestasi belajar matematika adalah sebesar 0,53. Dengan berpedoman pada interpretasi koefisien korelasi, maka korelasi antara variabel sikap belajar matematika dengan prestasi belajar matematika dan juga motivasi belajar terhadap prestasi belajar termasuk kategori hubungan yang cukup erat (moderate). Tanujaya, et al (2017), menyatakan bahwa kooefisien korelasi 0,40 - 0,60 dikelompokkan dalam kategori hubungan dua variabel yang moderate.

Jika koefisien korelasi bernilai positif maka dapat dinyatakan adanya hubungan yang positif antara variabel bebas dan variabel terikat. Sedangkan untuk menguji taraf signifikan antara dua variabel, adalah dengan membandingkan nilai $t_{\text {hitung }}$ dengan $t_{\text {tabel }}$ pada suatu taraf signifikansi tertentu, misalnya $5 \%$. Jika nilai $t_{\text {hitung }}$ lebih besar dari nilai $t_{\text {tabel }}$ maka hubungan tersebut signifikan. Sebaliknya jika nilai $t_{\text {hitung }}$ lebih kecil dari $t_{\text {tabel }}$ maka hubungan tersebut tidak signifikan

\section{Hubungan positif yang signifikan antara motivasi belajar dan prestasi belajar}

Sesuai hasil uji hipotesis dalam penelitian ini, didapati bahwa nilai korelasi antara motivasi belajar dengan prestasi belajar adalah $r=0,54$. Nilai korelasi ini terbukti sangat signifikan, di mana $F_{\text {hitung }}=18,10$ jauh lebih besar daripada $F_{\text {tabel }}=$ 4,06 .

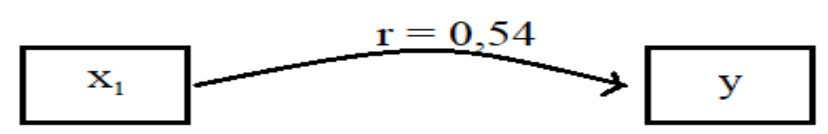

\section{Gambar 1. Hubungan antara Motivasi Belajar dengan Prestasi Belajar}

Makna dari nilai korelasi ini adalah bahwa motivasi belajar memiliki hubungan erat terhadap prestasi belajar. Karena nilai korelasi positif $(r=0,53)$ maka semakin tinggi nilai motivasi belajar, semakin tinggi pula prestasi belajar. Hal ini dapat dimaklumi karena sangat logis. Diakui bahwa motivasi adalah dorongan dari dalam diri sendiri. Dorongan inilah yang membuat seseorang mampu bekerja tanpa merasa lelah. Demikian juga dalam belajar, motivasi akan memberikan kekuatan besar bagi seorang siswa untuktekun belajar. Jadi, sangat wajar jika angka korelasinya positif.

Hasil penelitian ini menunjukkan bahwa skor terendah untuk motivasi belajar adalah 50 dan skor tertingginya adalah 72. Skor terendah untuk prestasi belajar adalah 65 dan skor tertingginya 90. Dari rentang skor pada kedua variable tersebut, didapati nilai korelasi $r=0,54$. Ini sebuah nilai korelasi positif. Artinya, secara akumulasi, 
antara variable motivasi belajar $x_{1}$ dengan hasil belajar $(y)$ memiliki pola hubungan searah. Maksudnya, siswa bernilai motivasi belajar yang tinggi, akan memperoleh nilai prestasi belajar yang tinggi pula. Sebaliknya, siswa bernilai motivasi rendah akan mengalami prestasi belajar yang rendah pula. Berdasarkan hasil penelitian ini, maka sampai kapan pun, korelasi antara motivasi belajar dengan hasi belajar ini diyakini terjadi secara positif, dengan tingkat keyakinan sebesar 95\% (karena $\alpha=5 \%$ ).

\section{Hubungan positif yang signifikan antara Sikap Belajar dan Prestasi Belajar}

Sesuai hasil uji hipotesis dalam penelitian ini, diperoleh bahwa nilai korelasi antara sikap belajar dengan prestasi belajar adalah $r=0,43$. Nilai korelasi ini terbukti sangat signifikan, di mana $F_{\text {hitung }}=9,96$ jauh lebih besar daripada $F_{\text {tabel }}=4,06$.

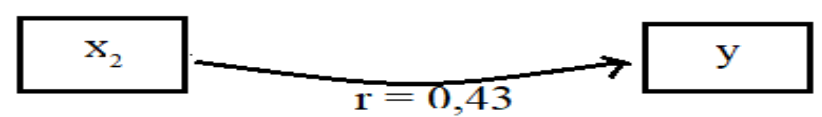

\section{Gambar 2. Hubungan antara Sikap Belajar dengan Prestasi Belajar}

Makna dari nilai korelasi ini adalah bahwa sikap belajar memiliki hubungan erat terhadap prestasi belajar. Karena nilai korelasi positif $(r=0,43)$ maka semakin tinggi skor sikap belajar, semakin tinggi pula prestasi belajar. Hal ini dapat diterima secara logis. Diakui bahwa sikap adalah bagian dari factor internal seorang siswa yang akan menentukan kapan, dengan siapa, dan bagaimana seorang siswa belajar. Semakin baik sikap belajar, maka kedisiplinan dan ketekunan belajar makin baik. Ini akan berdampak pada hasil belajar. Jadi, sangat wajar jika angka korelasinya positif dan signifikan.

Hasil penelitian ini menunjukkan bahwa skor terendah untuk sikap belajar adalah 60 dan skor tertingginya adalah 71 . Skor terendah untuk prestasi belajar adalah 65 dan skor tertingginya 90. Dari rentang skor pada kedua variable tersebut, didapati nilai korelasi sikap belajar dengan hasil belajar sebesar $r_{y . x 2}=0,43$. Ini sebuah nilai korelasi positif. Artinya, secara akumulasi, antara variabel sikap belajar $\left(x_{1}\right)$ dengan hasil belajar $(y)$ memiliki pola hubungan searah. Maksudnya, siswa bernilai tinggi padasikap belajar, akan memperoleh nilai tinggi pula pada prestasi belajar. Sebaliknya, siswa bernilai rendah pada sikapbelajar, akan mengalami prestasi belajar yang rendah pula.Berdasarkan hasil penelitian ini, maka sampai kapan pun, korelasi antara sikap belajar dengan hasi belajar ini diyakini terjadi secara positif, dengan tingkat keyakinan sebear 95\% (karena $\alpha=5 \%$ ). 


\section{Hubungan positif yang signifikan antara Motivasi Belajar, Sikap Belajar dan}

\section{Prestasi Belajar}

Sesuai hasil uji hipotesis dalam penelitian ini, didapati bahwa nilai korelasi antara motivasi belajar dan sikap belajar terhadap prestasi belajar adalah sebesar $r_{y \cdot x_{1} x_{2}}=0,61$. Nilai korelasi ini terbukti sangat signifikan, di mana $F_{\text {hitung }}=25,90$ jauh lebih besar dari nilai $F_{\text {tabel }}=3,21$.

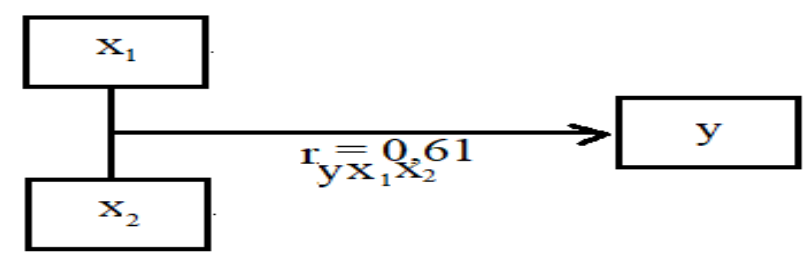

\section{Gambar 3. Hubungan antara Motivasi dan Sikap dengan Prestasi Belajar}

Makna dari nilai korelasi ini adalah bahwa kedua factor motivasi belajar dan sikap belajar, secara bersama-sama merupakan variable bebas yang memiliki hubungan erat terhadap prestasi belajar. Karena nilai korelasi positif $(r=0,61)$ maka semakin tinggi skor motivasi belajar dan sikap belajar, semakin tinggi pula nilai prestasi belajar. Hal ini dapat diterima secara logis. Diakui bahwa motivasi belajar dan sikap adalah bagian penting dari faktor-faktor penentu hasil belajar siswa. Jika sumber belajar disiapkan, tetapi siswa tidak memiliki motivasi belajar dan sikap belajar yang baik, maka sumber belajar tidak akan efektif, menjadi tidak berguna. Semakin baik motivasi dan sikap belajar, maka semangat, ketekunan dan kedisiplinan belajar makin baik. Ini akan berdampak positif kepada hasil belajar. Jadi, sangat wajar jika angka korelasinya positif dan signifikan.

Hasil penelitian ini menunjukkan bahwa skor terendah untuk sikap belajar adalah 60 dan skor tertingginya adalah 71. Skor terendah untuk motivasi belajar adalah 50 dan skor tertingginya 70. Skor terendah untuk prestasi belajar adalah 65 dan skor tertingginya 90. Skor terendah untuk prestasi belajar adalah 65 dan skor tertingginya 90. Dari rentang skor pada ketiga variable tersebut,, didapati nilai korelasi sikap belajar dengan hasil belajar sebesar $r_{y . x 2}=0,43$. Ini sebuah nilai korelasi positif. Artinya, secara akumulasi, antara variable sikap belajar $\left(x_{1}\right)$ dengan hasil belajar $(y)$ memiliki pola hubungan searah. Maksudnya, siswa bernilai tinggi pada sikap belajar, akan memperoleh nilai tinggi pula pada prestasi belajar. Sebaliknya, siswa bernilai rendah 
pada sikap belajar, akan mengalami prestasi belajar yang rendah pula. Berdasarkan hasil penelitian ini, maka sampai kapan pun, korelasi antara motivasi belajar dan sikap belajar terhadap hasil belajar ini diyakini terjadi secara positif, dengan tingkat keyakinan sebesar 95\% (karena $\alpha=5 \%)$.

\section{SIMPULAN}

Hasil penelitian menunjukan bahwa (1) terdapat hubungan positif dan signifikan antara sikap belajar terhadap prestasi belajar matematika siswa kelas VII SMP 6 Langke Rembong dengan koefisien korelasi sebesar 0,43 dengan besarnya sumbangan variabel sikap belajar terhadap prestasi belajar matematika siswa sebesar 18,49\%. Artinya bahwa jika Sikap belajar siswa tinggi, maka prestasi belajarnya juga tinggi. (2) terdapat hubungan positif dan signifikan anatara motivasi belajar terhadap prestasi belajar matematika siswa kelas VII SMP 6 Langke Rembong dengan koefisien korelasi sebesar 0,53 dengan besarnya sumbangan variabel sikap belajar terhadap prestasi belajar matematika siswa sebesar 28,09\%. Artinya bahwa jika Motivasi belajar siswa meningkat, maka prestasi belajarnya juga meningkat (3) terdapat hubungan positif dan signifikan anatra sikap belajar dan motivasi belajar terhadap prestasi belajar matematika siswa kelas VII SMP Negeri 6 Langke Rembong secara bersama-sama dengan koefisien korelasi sebesar 0,61 dengan besarnya sumbangan variabel sikap belajar dan motivasi belajar terhadap prestasi belajar matematika siswa sebesar 37,21\%. Artinya bahwa jika Sikap belajar dan motivasi belajar siswa meningkat, maka prestasi belajarnya juga meningkat

\section{DAFTAR RUJUKAN}

Djaali. 2008. Psikologi Pendidikan. Jakarta: Bumi Aksara.

Kartiwi, D. P. 2011. Pengaruh Pembelajaran Berbasis Masalah ditinjau dari Bakat Numerik dan Kecemasan Siswa terhadap Prestasi Belajar Matematika Siswa Kelas X SMA Negeri 1 Kuta. Jurnal Ilmiah Pendidikan dan Pembelajaran Ganesha, 7(2).

Moore, D. S., Notz, W. I., \& Fligner, N. A. 2013. The Basic Practice of Statistics. New York: W. H. Freeman and Company.

Mukhtar, R. 2015. Hubungan Motivasi Belajar dengan Hasil Belajar pada Mata Pelajaran Seni Budaya Bidang Seni Musik Siswa Kelas X SMA Piri 1 Yogyakarta. Skripsi, Yogyakarta: Universitas Negeri Yogyakarta. 
Ompusunggu, V. D. K. 2013. Peningkatan kemampuan pemahaman matematik dan sikap positif terhadap matematika siswa SMP Nasrani 2 Medan melalui pendekatan Problem Posing, Disertasi, Medan: Universitas Negeri Medan.

Sadirman. (2004). Interaksi dan Motivasi Belajar. Jakarta: PT Rineka Cipta

Siagian, R. E. F. 2015. Pengaruh minat dan kebiasaan belajar siswa terrhadap prestasi belajar matematika. Formatif, Jurnal Ilmiah Pendidikan MIPA, 2(2).

Sudarto, Z. (2016). Implementasi kebijakan penyelenggaraan pendidikan inklusif. Jurnal Pendidikan (Teori dan Praktik), 1(1), 97-106.

Suherman, dkk. 2003. Strategi Pembelajaran Matematika Kontemporer. Bandung: FMIPA Universitas Pendidikan Indonesia.

Susilo, T. A. B. 2017. Pengaruh Sikap Siswa pada Matematika terhadap Hasil Belajar Matematika di SMP. Jurnal Pendidikan Matematika, 3(1), 9-16.

Tanujaya, B., Jeinne Mumu, dan Gaguk Margono, 2017. The relationship between Higher Order Thinking Skills and Academic Performance of Students in Mathematics Instruction. International Education Studies, 10 (11). Doi: 10.5539/iesv10n11p78.

Walgito, B. 2002. Psikologi Sosial: Suatu Pengantar. Yogyakarta: Andi Offset. 